\title{
Devolution of Potato and Its Method of Restoration
}

\section{Kazim Garakishi Huseynov}

Entomology Department, Science Research Institute of Plant Protection and Technical Crops (SRIPP and TC), Ganja, Azerbaijan

Email: kazimhuseyni@mail.ru

How to cite this paper: Huseynov, K.G. (2016) Devolution of Potato and Its Method of Restoration. Open Access Library Journal, 3: e2976.

http://dx.doi.org/10.4236/oalib.1102976

Received: August 12, 2016

Accepted: September 11, 2016

Published: September 14, 2016

Copyright $\odot 2016$ by author and Open Access Library Inc.

This work is licensed under the Creative Commons Attribution International License (CC BY 4.0).

http://creativecommons.org/licenses/by/4.0/

\section{(c) (i) Open Access}

\begin{abstract}
Potato is one of the important strategic areas of agriculture that plays an important role in ensuring of food security. For this, there is a great need for healthy seed material. Research shows that high-quality seed potatoes for the production of seed material which prevents the supply of specified environmental factors have been taken in order to reduce their impact. The ecological condition of Azerbaijan republic allows their cultivation depending on the vertical zone cultivated in different ecological environment.
\end{abstract}

\section{Subject Areas}

Agricultural Science, Plant Science, Soil Science

\section{Keywords}

Potato, Devaluation, Depravation, Degenerate, Early Spring Sowing, Spring Sowing, Summer Sowing

\section{Introduction}

Ganja-Gazakh region of Azerbaijan republic is situated from 69 meters to $2470 \mathrm{~m}$ above the sea level (Samukh region, Nabiagali City, Shamkir region, Goygol stations). In vertical zone of agrosenoses, potato plants have direct impact to the beneficial and harmful entomofauna on the development of the influential factors in the local environment. Thus, elsewhere in the same environmental conditions there are positive and negative impacts on the development of plants. The negative impacts of environmental factors cause to the sharp decrease in productivity. Tuber formation process in potato plant is regulated by environmental factors. The abiotic factors play an important role in the environmental factors [1]. 


\section{Materials and Methods}

Devaluation are observed in Azerbaijan in the seed of potato. Nowadays devaluation spread in all region our country. This process is dangerously for potato growing [2] [3]. We study biological, ecological and other features of potato according to methods of Podgorniy P.I. (1957), Yakushkina I.V., Chmora N.Y. (1955), Lisenco T.D. (1952). It was work out integration measures against of devaluation on sowing of potato.

\section{Action of ecological factors:}

To form of potato tuber is regulating with ecological factors. Abiotic factors take an important part among the ecological factors. High temperature (more than $25^{\circ} \mathrm{C}$ ) negative to influence to develop the potato. The temperature which is more than $25^{\circ} \mathrm{C}$ cause to devaluation of plant of potato. In any way high temperature cause intervals in the process of photosynthesis and it is late the potato tuber. When the process of photosynthesis is restoring it is observed that development other normally and in the result of process pea is going in potato tuber. Sometimes high temperature influence in fresh potato tuber the developing of shoots and cause to become worse the quality of harvest [4].

Insufficiency of the dampness of the land cause devaluation and depravation. When dimity dampness decrease quantity of water and it is late the process of photosynthesis and it creates condition of development other normally.

There are some ideas about devaluation and depravation. Investigations note that these factors cause the devaluation and depravation:

1) To be infections disease;

2) To be the mikorizain the root of the potato;

3) Productivity of once in two years;

4) Land influence of the climate condition;

5) Unsatisfactory agro technical service;

6) Spreading virus disease.

Other observations put in a claim for the cause of the devaluation is increase of plant with the vegetative way. Because that devaluation and depravation must specify with biological basics. Observations show that observing from changes in the devaluation of potato tuber. These form changes is the result of the process is going on potato tuber. Changes which observing that potato plant influence negative against the factors of environment [5].

If natural factors is unsuitable for development potato plant, the vegetative organs lose characters which belong of sort. For example, the influence of high temperature is connected the character of devaluation. Devaluation is connected with development of step by step of potato plant. The plant has different characters in the some steps. If we observed in potato plant physiological process as the same in flowering plants we come to a conclusion that changes in stage go only point of height of plant. That is why up tier of plant is young but in stage is old. The basic part of shoot is old but in stage is young. This reason that by stage of development is passed to other cell. The process which is going a green mass is discovered in potato tuber. Observation shows that eyes 
ungula distribute on potato tuber. Eyes to come across more in part of tuber. The down part of tuber grow languid for this reason bigger distance among the eyes. Development begin in the potato tuber only this part. Observation show that when the bud which is grow up influence high temperature (for example, ecological factors) the physiological changes cause devaluation in eyes.

Devaluation and depravation is peculiar sigh to potato plant, that' is why disadvantageous soil-climate condition and agro technical events which is not right can only quicken this process. It shows that these process don't phenotypic, they are genotypic sighs. Researches show that metabolism is disturb bed while the temperature raise and it makes the condition of unnormal nutrition and it gives a chance to devaluation. During long term drought the development of root tubers stop and after rain and irrigation the tubers begin to develop and it cause to depravation [6].

Small tubers on the tubers are formed and they use little from carbohydrate. A part of carbohydrate is collected on the leaf. From this reason leaves develop at great speed. The vein on the leaves develop too much and it cause to wrap the edge of leaves and it makes conditions the disease of leaves [7].

\section{Results and Discussions}

Researches done in 2003-2015 years show that when we use 4 - 5 same sort above 1470 $\mathrm{m}$ sea level (Gadabay region, Slavyanka village) we observe devaluation on the potato tubers. When we do saving with the same sort above $500 \mathrm{~m}$ sea level as a result of devaluation productivity diminishes. For clearing the reason of devaluation, experiment which consist of 3 variant are put above $500 \mathrm{~m}$ sea level in 2008-2012. With the purpose of this Milva and Amiri 600-I sorts are laid in for the first and second variant growing in the same area. In the third variant Amiri-600-II laid in from Gadabay region Slavyanka village are used.

Above $500 \mathrm{~m}$ sea level (in Gizilgaya settlement) Milva and Amiri-600-I sort of potato is laid in from early and summer sowing. The sort of Amiri-600-II planted laying seed every year from Gadabay region, Slavyanka village produced from the same sort (seed material is not changed).

Researches show once more that devaluation and depravation and etc. belong to potato tuber. But ecological factors speed this process. Till in the area above $500 \mathrm{~m}$ sea level devaluation in seed material which bought from potato sowing is observed in the third year. But in seed bought from Gadabay region Slavyanka village (above $1470 \mathrm{~m}$ sea level) devaluation is observed (same seed have been used for 5 year). The reason of observation of devaluation some year late-fifth year is plant of potato plant in advantageous condition from ecological looking.

Researches show that the main reason of devaluation is to plant potato with the same seed-vegetative organ and in the same ecological condition. Seed material (vegetative organ) must be changed in high area till above $700 \mathrm{~m}$ sea level once $2-3$ year and in the highest area it must be changed once 4 - 5 year, for potato tubers can tdevaluate.

Using from this table we can give opportunity to get better quality of potato sort, to 
defend biomorfological peculiarity belonging to the sort, to develop vegetative plant material continuous (Table 1). This can raise productivity of potato plant, can solve problems, help not to perish sort having productive and the quality of high nutrition. Researches show that potato tubers which taken from spring sowing are more advantageous for summer sowing.

But in early sowing tubers having the quality of vegetative sowing material bought from spring and summer sowings must be used. In other point it difficult to get vegetative sowing material from tubers collected from early sowings. For getting potato tuber from early sowing tubers must past silence period in less time. For this we must do the seeds of potato tuber are secured better air. At that time breathing process speeds and it cause to turn dissolved matters into solved matter. The eyes of potato tuber grow much better for accepting solved matter much more to achieve this process harvest must be collected early from early sowing.

Such peel of potato tuber doesn't firm and aired in the seeds speed. Unripen potato tuber must collect till the end of blossom (when plants blossom 70\% - 75\%). There are more number of carbohydrates in such tuber. Tubers which is rich with sugar grow earlier. High temperature and humidity is need for germinating seed potato tuber. Potato jells overturns sugar and breathing quickens. Being humidity high it gives chance to swell plasma and to disturbed silence period. There are a lot of stock nutrition things in the potato tuber that is why the area must be watered some days ago. Gathered seed material must be kept in temperature $27^{\circ} \mathrm{C}-32^{\circ} \mathrm{C}$ and in the moisture of $90 \%-95 \%$. Temperature shorts the time of silence period. Aria must be watered after sowing once ten days.

But if we do sowing early with early-ripen potato sort at that time green mass must be cut up $6-8 \mathrm{sm}$ and gathering of harvest must fulfill after 70\%-75\%. At that time the process of tuber is formotion is late in the early ripen sort and tubers are suitable for summer sowing. "Physiological aging" is observed when we keep seeds buying early (till up $400 \mathrm{~m}$ sea level) and spring sowing (till up $700 \mathrm{~m}$ sea level) in the tuber a long time. Ecological condition (high temperature, minority of humid, long day and etc.) is suitable for physiological ripe of potato tuber. Under existing conditions devaluation is observed. But physiological ripening is not observed in summer sowing, such tubers inclined to the development and harvests which forms from the same tubers don't degenerate.

It shows that summer sowings buying from early sowing forming from seed material

Table 1. Devaluation of potato tubers.

\begin{tabular}{|c|c|c|c|c|c|c|c|c|c|c|c|}
\hline \multirow{3}{*}{$\begin{array}{l}\text { Sort of } \\
\text { potato }\end{array}$} & \multirow{3}{*}{$\begin{array}{l}\text { Altitude of } \\
\text { the sea level }\end{array}$} & \multicolumn{10}{|c|}{ Research years during 2008-2012 } \\
\hline & & \multicolumn{5}{|c|}{ Devaluation, in \% } & \multicolumn{5}{|c|}{ Crop capacity, in $\mathrm{t} / \mathrm{ha}$} \\
\hline & & 2008 & 2009 & 2010 & 2011 & 2012 & 2008 & 2009 & 2010 & 2011 & 2012 \\
\hline Milva & 500 & - & - & - & 7.0 & 6.0 & 26 & 30 & 28 & 22 & 16 \\
\hline Amiri-600-I & 500 & - & - & - & 14.0 & 17.0 & 24 & 27 & 24 & 14 & 13 \\
\hline Amiri-600-II & 1341 & - & - & - & - & - & 28 & 27.5 & 30 & 26 & 28 \\
\hline
\end{tabular}




\section{Spring sowing}

(a.s.l. more than $800 \mathrm{~m}$.)

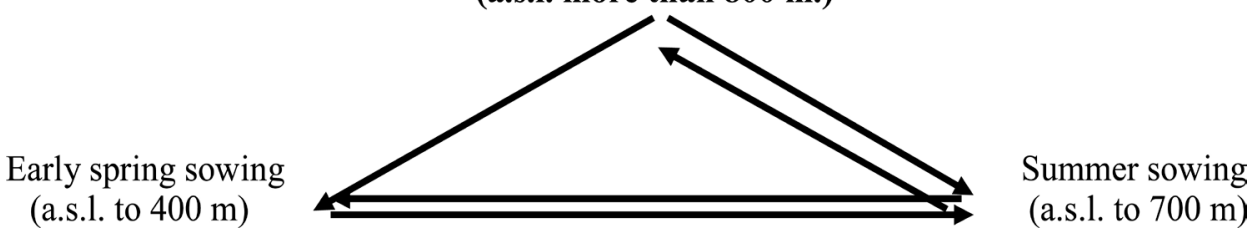

Scheme 1. Prevention devaluation and depravation on the potato sowing.

stops not only development of uninfection disease (devaluation, depravation and etc.) but also raise the resistance of seed material to this process. Observations show that observing anomalies in the potato tuber are not created by the effect of ecological factors. Researches doing 2003-2014 show that when we do early sowing with the seed material which bought from potato sort Amiri-600 used in summer sowing unnormal development is observed (Scheme 1). It shows that abnormal development (devaluation, depravation and etc.) in the potato tuber is not only the Prevention devaluation and depravation on the potato sowing influence of ecological factors but also it is physiological aging of sort as a result of vegetative propagate. Ecological factors speed and clear these process. That is why seed material must be changed in farmer economy once 3 - 4 years. In other point seed material must be bought from tubers which grown in higher aria.

\section{Conclusions of Researches}

1) The favorable environmental factors in mountainous areas inhibit the physiological aging in potato tubers.

2) Disadvantageous ecological factors including abiotic factors speed devaluation.

3) Wild or abnormal development is observed not only in the potato tubers but also in green mass of potato.

4) There is reduced productivity of potatoes by repeated planting depending not on fertile or every year fertilised areas. The reason is that sowing layer is poisoned by fitonsids secreted by plant.

5) The main reason of devaluation is vegetative rise of the same sort in potato plant more than three years.

6) To avoid of becoming the wild or abnormal development in plants there must be provided works by the scheme implementation of the summer planting and the seed materials should be changed after every 3 - 4 years.

\section{References}

[1] Podgorniy, P.I. (1957) Plant-Growing. Selchozgiz, Moscow, 608 p. (In Russia)

[2] Yakushkina, I.V. and Chmora, N.Y. (1955) Potato. State Publishing House Agricultural Literature, Moscow, 263 p. (In Russia)

[3] Arnautov, V.V. (1959) Potato. Sovetskaya Russia, Moscow, 95 p. (In Russia)

[4] Kholmckvist, A.A. (1972) Keeping of Potato and Vegetable. Kolos, Leninqrad (Sankt St. Petersburq), 279 p. (In Russia) 
[5] Huseynov, K.G. (2012) Dependence of the Sowing Time (Period) of the Potato from Vertical Zone. Folium, Moscow, No. 4, 44 p. (In Russia)

[6] Chmora, N.Y. and Arnautov, V.V. (1953) Potato. State Publishing House Agricultural Literature, Moscow, 566 p. (In Russia)

[7] Lisenco, T.D. (1952) Step by Step Development of the Plants. State Publishing House Agricultural Literature, Moscow, 711 p. (In Russia)

Submit or recommend next manuscript to OALib Journal and we will provide best service for you:

- Publication frequency: Monthly

- 9 subject areas of science, technology and medicine

- Fair and rigorous peer-review system

- Fast publication process

- Article promotion in various social networking sites (LinkedIn, Facebook, Twitter, etc.)

- Maximum dissemination of your research work

Submit Your Paper Online: Click Here to Submit

Contact Us: service@oalib.com 